\title{
Detection of Neospora caninum and Toxoplasma gondii in Semen of Naturally Infected Rams
}

\author{
Marilia de Oliveira Koch', Rosangela Locatelli Dittrich', Romildo Romualdo Weiss', \\ Tácia Gomes Bergstein-Galan4, Daniel Moura Aguiar², Yara de Oliveira Brandão', \\ Amilcar Arenal Cruz ${ }^{3}$, Ana Paula Brenner Busch'1 \& Alda Lúcia Gomes Monteiro'1
}

\begin{abstract}
Background: Neospora caninum and Toxoplasma gondii are closely related cyst-forming apicomplexan parasites identified as important causes of reproductive failure in cattle. Moreover, abortion cases attributed to N. caninum and T. gondii infection have been occasionally reported in sheep. Due to the relatively scarce information on the molecular detection of $N$. caninum in the semen of naturally infected rams, this study aimed to detect parasitic DNA in fresh semen samples and in frozen extended semen straws from male sheep from artificial inseminations centers in Southern Brazil.

Materials, Methods \& Results: Semen samples of 38 rams from artificial insemination centers were evaluated. Eleven rams were naturally infected (seropositive for anti-N. caninum and/or anti-T. gondii IgG) and were selected for fresh semen collection. We tested all the samples for the closely related protozoan $T$. gondii to detect a possible cross-reaction and co-infection, due to the close similarity with $N$. caninum. The indirect fluorescent antibody test was used to detect IgG antibodies in the 11 serum samples from rams. Fresh semen samples were collected from 11 rams on days 1, 50, 55, and 58 using an artificial vagina and ewe in estrus. Other 27 rams had their frozen extended semen straws analyzed. A total of 20 fresh semen samples and 27 frozen extended semen straws samples were used to detect the presence of $N$. caninum and $T$. gondii DNA by polymerase chain reaction (PCR). Nc-5 and B1 genes were used as target regions to detect $N$. caninum and $T$. gondii DNA, respectively. The presence of $N$. caninum DNA was confirmed in the third collection of a fresh semen sample of one seropositive ram. $T$. gondii DNA was detected in a fresh semen sample of one seropositive ram. The DNA sequences of $186 \mathrm{bp}$ from $N$. caninum (GenBank accession: MH806393) and 492 bp from T. gondii (GenBank accession: MH793503) were obtained by sequencing, and analysis revealed $99 \%$ and $100 \%$ identity, respectively, compared with other sequences deposited at GenBank. $N$. caninum and T. gondii DNAs were not detected in any of the 27 frozen extended semen straws used for artificial insemination. Discussion: This study demonstrated the presence of $N$. caninum and T. gondii DNA in fresh semen samples of naturally infected rams. The non-detection of N. caninum and T. gondii DNA in frozen semen samples of rams could be due to the dilution that was used to prepare the semen straws (GGL diluent and 5\% glycerol), since fresh semen samples were not diluted prior to the test. Moreover, in our study, the volume of frozen semen samples $(0.25 \mathrm{~mL})$ used for PCR was lower than the volume of sediment obtained from fresh semen $(0.5 \mathrm{~mL})$, and the fresh semen centrifugation to obtain the sediment may have grouped the tachyzoites, increasing the sensitivity of the technique employed. No high IgG serological titers were detected in the rams at the time they were eliminating the parasite through fresh semen. The final titer of anti- $N$. caninum and anti-T. gondii IgGs in serum was 1:100, suggesting chronic infection. It is suggested that a new parasite elimination pathway is occurring among rams used for reproduction, due to the presence of $N$. caninum and T. gondii DNA in fresh semen samples from seropositive animals. Although the detection of genomic DNA of N. caninum and T. gondii in semen does not necessarily imply the presence of infectious stages of the parasites and does not determine their viability, these results demonstrate the need for further studies. Our study also indicates the need to reinforce preventive measures for sheep in artificial insemination centers until the risks are evaluated, by performing serological examinations with anti- $N$. caninum and anti-T. gondii antibodies, for instance, to select the rams that will be used for breeding.
\end{abstract}

Keywords: male sheep, ewes, ovine, tachyzoites, frozen extended semen straws, fresh semen.

DOI: $10.22456 / 1679-9216.92090$

Received: 10 January 2019 Accepted: 8 April 2019 Published: 2 May 2019

${ }^{1}$ Universidade Federal do Paraná (UFPR), Curitiba, PR, Brazil. ${ }^{2}$ Faculdade de Medicina Veterinária, Universidade Federal do Mato Grosso (UFMT), Cuiabá, MT, Brazil. ${ }^{3}$ Universidade de Camagüey, Camagüey, Cuba. ${ }^{4}$ Universidade Positivo (UP), Curitiba. CORRESPONDENCE: M.O. Koch [mariliakoch@ufpr.br - Tel.: +55 (41) 3350-5740]. Programa de Pós-graduação em Ciências Veterinárias, UFPR. Rua dos Funcionários n. 1540. Bairro Cabral. CEP 80035-060 Curitiba, PR, Brazil. 


\section{INTRODUCTION}

Natural infection of sheep by Neospora caninum was first identified in 1990 [12], and Toxoplasma gondii infection was described for the first time in 1942 [32]. Neospora caninum and Toxoplasma gondii are closely related cyst-forming apicomplexan parasites identified as important causes of reproductive failure in cattle $[13,14]$. Abortion cases attributed to $N$. caninum [12,21,35] and T. gondii [10,20,28,44] infection have been occasionally reported in sheep. These parasites have already been identified in $77 \%$ of 74 brain samples from aborted sheep fetuses [23].

The presence of $N$. caninum DNA in the semen of naturally infected bulls $[7,11,17,18,24,33,40]$ and experimentally infected rams was reported [42]. Experimental studies showed the presence of $T$. gondii in the semen and/or reproductive tract of dogs [2], goats [15,38], swine [31], cattle [39], and rams [1,27,41,43]. Studies performed with naturally infected animals have shown the detection of $T$. gondii only in the semen of rams [4,29] and dogs [25], suggesting a new route of elimination of the parasite that can cause reproductive damage and be sexually transmitted [9]. Studies have only found $N$. caninum DNA in frozen extended semen straws samples from cattle $[7,33,40]$.

Due to the relatively scarce information on the molecular detection of $N$. caninum in the semen of naturally infected rams, this study aimed to detect parasitic DNA in fresh semen samples and in frozen extended semen straws from male sheep from artificial inseminations centers in Southern Brazil. We tested all the samples for the closely related protozoan $T$. gondii to detect a possible cross-reaction and co-infection, due to the close similarity with $N$. caninum.

\section{MATERIALS AND METHODS}

\section{Animals and samples}

Thirty-eight rams aged 1-6 years (Dorper, Texel, White Dorper, Suffolk, and crossbreed), with no history of reproductive problems, from three rural properties with sporadic occurrences of abortions in pregnant ewes, in the state of Paraná, Southern Brazil, were included in this study to detect $N$. caninum and $T$. gondii DNA in fresh and frozen semen samples.

Twenty semen samples were collected from 11 rams seropositive for $N$. caninum and/or T. gondii IgG antibodies (identified with numbers 1-11) that had been selected to detect $N$. caninum and $T$. gondii DNA in fresh semen samples. Twenty-seven frozen extended semen straws samples from 27 other breeding rams belonging to the same rural properties were used to detect $N$. caninum and $T$. gondii DNA. Since we did not have access to these animals, serological data is not known.

Samples of fresh semen were collected using an artificial vagina and according to the availability of ewes in estrus. Fifteen min after collecting semen samples, blood samples were collected without anticoagulant by puncturing the jugular vein. Blood and semen samples from the 11 rams were collected on days 1, 50, 55 and 58. Samples were refrigerated at $4^{\circ} \mathrm{C}$ and transported to the laboratory within $2 \mathrm{~h}$.

Sera from the 11 rams were obtained by centrifuging the blood at $3000 \times g$ for $10 \mathrm{~min}$ and, then, stored at $-20^{\circ} \mathrm{C}$ until processing. The 20 fresh semen samples (the total volume of ejaculates ranged from $1.0-2.0 \mathrm{~mL}$ ) were centrifuged at $1000 \times \mathrm{g}$ for $10 \mathrm{~min}$, and the sediments of approximately $0.5 \mathrm{~mL}$ were frozen at $-20^{\circ} \mathrm{C}$ before DNA extraction.

The 27 semen straws frozen in 5\% glycerol with $0.25 \mathrm{~mL}$ of extender GGL (Glycine-Yolk-Milk), and approximately 100 million spermatozoa per dose $\left(400 \times 10^{6} / \mathrm{mL}\right)$ were refrigerated at $4^{\circ} \mathrm{C}$ for approximately $4 \mathrm{~h}$ during the transport to the laboratory. Then, $0.25 \mathrm{~mL}$ of the sample transferred to micro-tubes and frozen at $-20^{\circ} \mathrm{C}$ until processing.

\section{Indirect fluorescent antibody test (IFAT)}

The indirect fluorescent antibody test was used to detect IgG antibodies against $N$. caninum and $T$. gondii in the 11 serum samples from rams [30]. Slides were prepared containing tachyzoites of $N$. caninum (NC-1 strain) and $T$. gondii (RH strain), obtained through cell culturing as described by Locatelli-Dittrich et al. [26]. Serum samples with titers 1:25 for N. caninum and 1:40 for $T$. gondii were considered positive as described by Guimarães et al. [22]. Sera were analyzed until reaching the final titer. All IFATs included known positive and negative ram serum samples as control. All samples were processed twice to ensure the quality of the results. The Monoclonal Anti-Goat/Sheep IgGFITC antibody ${ }^{1}(\mathrm{~F} 4891)$ was used at a dilution of 1:100.

\section{Collection of semen}

Fresh semen samples were collected from 11 seropositive rams on days $1,50,55$, and 58 using an 
artificial vagina and ewe in estrus. The artificial vagina consisted in a $20 \mathrm{~cm} \times 6 \mathrm{~cm}$ rigid tube and a flexible rubber tube. The space between the rigid and the flexible tube was filled with warm water at $55^{\circ} \mathrm{C}$, so that the inside of the artificial vagina reached a temperature between $42^{\circ} \mathrm{C}$ and $45^{\circ} \mathrm{C}$. The artificial vagina membrane was lubricated with aqueous base gel. When the ram jumped over the ewe, his penis was gently diverted into the artificial vagina, and the ejaculate was deposited in the collection tube [16].

DNA extraction

The DNA extraction from 20 fresh semen samples (containing $0.5 \mathrm{~mL}$ of semen sediment) and 27 frozen semen straws (containing $0.25 \mathrm{~mL}$ of sample) was performed using the PureLink® Genomic DNA Mini Kits².

Hemi-Nested PCR to detect Neospora caninum DNA

Hemi-nested PCR was performed to detect the presence of $N$. caninum DNA by using the primer pairs Np4/Np7 and Np6/Np7 of the pNC-5 gene of $N$. caninum [46], following the protocol previously published with some modifications [3]. The 25- $\mu \mathrm{L}$ PCR mixture contained $80 \mathrm{ng}$ of target DNA, $1.5 \mathrm{mM}$ of $\mathrm{MgCl}_{2}, 0.2 \mathrm{mM}$ of dNTPs, $1 \mathrm{U} /$ reaction of Taq polymerase, $1 \times$ buffer, $0.5 \mathrm{pmol} / \mu \mathrm{L}$ of primers, and Milli-Q Water qsp. PCRs using Np4/Np7 were performed in a thermocycler for 30 cycles of denaturation at $94^{\circ} \mathrm{C}$ for $30 \mathrm{~s}$, annealing at $55^{\circ} \mathrm{C}$ for $30 \mathrm{~s}$, and extension at $72^{\circ} \mathrm{C}$ for $30 \mathrm{~s}$. For the second round, with primers Np6/ $\mathrm{Np} 7,1 \mu \mathrm{L}$ of amplicon solution from the first-round Np4/Np7 PCR was used as target DNA, with the same PCR mixture, with 25 cycles of denaturation at $94^{\circ} \mathrm{C}$ for $30 \mathrm{~s}$, annealing at $54^{\circ} \mathrm{C}$ for $30 \mathrm{~s}$, and extension at $72^{\circ} \mathrm{C}$ for $30 \mathrm{~s}$. The secondary amplification products had a size of 227 bp. Positive (purified N. caninum tachyzoite DNA of the NC-1 strain) and negative (no DNA) controls were included in each PCR run. Amplicons were resolved on a $1.5 \%$ agarose gel, which was stained with SYBR ${ }^{3}{ }^{3}$ Safe DNA gel stain (Kasvi, K9-16C) and visualized under UV light.

Nested PCR to detect Toxoplasma gondii DNA

The presence of $T$. gondii DNA in the samples was addressed by a Nested PCR in which the target was part of the sequence of the repetitive gene B1 [5], following the protocol previously published with some modifications [19]. T. gondii DNA amplification was carried out in a $25-\mu \mathrm{L}$ reaction volume containing $80 \mathrm{ng}$ of target DNA, $1.5 \mathrm{mM}$ of $\mathrm{MgCl} 2,0.2 \mathrm{mM}$ of dNTPs, 1 U/reaction of Taq polymerase, $1 \times$ buffer, $0.5 \mathrm{pmol} / \mu \mathrm{L}$ of primers, and Milli-Q Water qsp. The primers used in the first round were those corresponding to gene B1 nucleotides 694-714 and 887-868. PCR was performed for 30 cycles of denaturation at $94^{\circ} \mathrm{C}$ for $30 \mathrm{~s}$, annealing at $56^{\circ} \mathrm{C}$ for $30 \mathrm{~s}$, and extension at $72^{\circ} \mathrm{C}$ for $30 \mathrm{~s}$. The primers used in the second round corresponded to gene B1 nucleotides 757-776 and 853-831 and were used in a reaction with $0.5 \mu \mathrm{L}$ of the amplicon solution from the first-round PCR as target DNA, with the same PCR mixture, with 20 cycles of denaturation at $94^{\circ} \mathrm{C}$ for 30 $\mathrm{s}$, annealing at $60^{\circ} \mathrm{C}$ for $35 \mathrm{~s}$, and extension at $72^{\circ} \mathrm{C}$ for $30 \mathrm{~s}$. The secondary amplification products had a size of $97 \mathrm{bp}$. Positive (DNA from T. gondii tachyzoites of the RH strain) and negative (no DNA) controls were included in each PCR run. Amplicons were resolved on a $1.5 \%$ agarose gel, which was stained with SYBR ${ }^{\circledR}$ Safe DNA gel stain (Kasvi, K9-16C) and visualized under UV light.

\section{Sequencing analysis}

PCR products were purified using PureLink ${ }^{\circledR}$ Quick Gel Extraction $\mathrm{Kit}^{2}$ according to manufacturer's instructions, and sequence analysis was performed using primer Np7, 5' GGGTGAACCGAGGGAGTTG3', to identify the DNA sequence of $N$. caninum [3] and primer 5'TGCATAGGTTGCCAGTCACTG'3, which corresponds to the gene B1 nucleotides 853-831, to identify the DNA sequence of T. gondii [19]. Sequence analysis was performed using the Big Dye Terminator Kit (Applied Biosystems) according to manufacturer's instructions in an ABI DNA Model 3500 Series Genetic Analyzer (Applied Biosystems).

Sequences were, then, subjected to BlastN analysis using the GenBank database at NCBI to confirm that the PCR-amplified sequences were those of N. caninum and $T$. gondii.

\section{RESULTS}

The anti- $N$. caninum $\mathrm{IgG}$ titer ranged from $1: 25$ to a maximum titer of $1: 100$ in the ram serum samples. The anti-T. gondii IgG titer ranged from 1:40 to a maximum titer of 1:100 (Table 1). Serum samples were considered positive to the presence of $N$. caninum and $T$. gondii if the entire surface of the tachyzoites was fluorescent. 
Among the 20 fresh semen samples from the 11 rams, $N$. caninum DNA was detected in the semen of ram 1 , collected on day 55 (Table 2). T. gondii DNA was detected in the fresh semen sample of ram 7, on day 1 (Table 2).

$N$. caninum and/or $T$. gondii DNA were not detected in any of the 27 frozen extended semen straws.
The DNA sequences of $186 \mathrm{bp}$ from N. caninum (GenBank accession: MH806393) and 492 bp from T. gondii (GenBank accession: MH793503) were obtained by sequencing, and analysis revealed $99 \%$ and $100 \%$ identity with sequences deposited at GenBank, respectively.

Table 1. Titers of anti-Neospora caninum and anti-Toxoplasma gondii IgGs detected by means of indirect fluorescence test (IFAT) in the serum of 11 rams.

\begin{tabular}{ccccccccc}
\hline \multirow{2}{*}{ Ram } & \multicolumn{3}{c}{ Day 1 } & \multicolumn{2}{c}{ Day 50 } & \multicolumn{2}{c}{ Day 55 } & \multicolumn{2}{c}{ Day 58 } \\
\cline { 2 - 8 } & T.gondii & N. caninum & T.gondii & N. caninum & T.gondii & N. caninum & T.gondii & N. caninum \\
\hline 1 & - & $1: 50$ & $1: 40$ & $1: 50$ & $1: 40$ & $1: 50$ & nd & nd \\
2 & $1: 40$ & - & $1: 40$ & - & - & - & nd & nd \\
3 & $1: 40$ & - & $1: 100$ & - & $1: 100$ & - & nd & nd \\
4 & - & $1: 100$ & nd & nd & nd & nd & - & $1: 50$ \\
5 & - & $1: 25$ & nd & nd & nd & nd & - & $1: 25$ \\
6 & $1: 40$ & - & nd & nd & nd & nd & - & - \\
7 & $1: 40$ & - & nd & nd & nd & nd & nd & nd \\
8 & $1: 100$ & - & nd & nd & nd & nd & nd & nd \\
9 & $1: 40$ & - & nd & nd & nd & nd & nd & nd \\
10 & - & $1: 25$ & nd & nd & nd & nd & nd & nd \\
11 & - & $1: 50$ & nd & nd & nd & nd & nd & nd \\
\hline
\end{tabular}

Negative: -; nd: no sample available.

Table 2. Detection of Neospora caninum and Toxoplasma gondii DNA in fresh semen samples from 11 rams using Hemi-Nested PCR and Nested PCR.

\begin{tabular}{ccccc}
\hline \multirow{2}{*}{ Ram } & Day 1 & Day 50 & Day 55 & Day 58 \\
\cline { 2 - 5 } & PCR & PCR & PCR & PCR \\
\hline 1 & - & - & N. caninum DNA & nd \\
2 & - & - & - & nd \\
3 & - & - & - & nd \\
4 & - & nd & nd & - \\
5 & - & nd & nd & - \\
6 & - & nd & nd & - \\
7 & T. gondii DNA & nd & nd & nd \\
8 & - & nd & nd & nd \\
9 & - & nd & nd & nd \\
10 & - & nd & nd & nd \\
11 & - & nd & nd & nd \\
\hline
\end{tabular}

Negative: -; nd: no sample available. 


\section{DISCUSSION}

In our study, $N$. caninum DNA was detected in the semen sample from the third collection from ram 1, in agreement with Syed-Hussain et al. [42] that detected $N$. caninum DNA in the semen samples of experimentally infected seropositive rams and also demonstrated sporadic parasite elimination between the first and fourth week after infection.

The ram in which semen $N$. caninum DNA was detected was seropositive for anti- $N$. caninum (1:50) and anti-T. gondii (1:40) IgGs. Co-infection in sheep has been reported in abortion cases by Hughes et al. [23], who detected the simultaneous presence of both parasites in $12.2 \%$ of brain samples from aborted sheep fetuses.

No high IgG serological titers were detected in the rams at the time they were eliminating the parasite through semen. The final titer of anti- $N$. caninum and anti-T. gondii IgGs in serum was 1:100, suggesting chronic infection. Studies on serological titration of ewes that presented abortion showed titers of 1:1024 [6] and 1:800 [45] for infection with T. gondii and $N$. caninum, respectively, and high titration of IgG suggests acute toxoplasmosis.

The DNA of $T$. gondii was detected in the semen of ram 7, in agreement with other studies that detected T. gondii DNA in samples of fresh and frozen semen from naturally infected rams used for reproduction [4,29].

In our study, T. gondii and N. caninum DNAs were not detected in the 27 frozen extended semen straws used for artificial insemination. This result is different from that in the study from Bezerra et al. [4], where $T$. gondii DNA was detected in $22.2 \%$ of frozen semen samples and in $100 \%$ of fresh semen samples from seropositive rams commercialized in artificial insemination centers in Northeastern Brazil.

The non-detection of $N$. caninum and $T$. gondii DNA in frozen semen samples of rams could be also due to the dilution that was used to prepare the semen straws (GGL diluent and 5\% glycerol), since fresh semen samples were not diluted prior to the test. Moreover, in our study, the volume of frozen semen samples $(0.25 \mathrm{~mL})$ used for PCR was lower than the volume of sediment obtained from fresh semen ( 0.5 $\mathrm{mL}$ ), and the fresh semen centrifugation to obtain the sediment may have grouped the tachyzoites, increasing the sensitivity of the technique employed.
Ortega-Mora et al. [33] investigated the presence of $N$. caninum DNA in fresh non-extended semen straws and frozen extended semen straws of eight bulls and detected a smaller number of positive samples in frozen semen than in fresh, indicating that positive results may be considered as confirmatory, but negative results cannot be considered as true negative.

Caetano-Da-Silva et al. [7] detected Neospora DNA sporadically in frozen semen samples from seropositive cattle. They also demonstrated that the nondetection of protozoa DNA in frozen semen samples can be explained by the low number of parasites in the sample, which is undetectable by the technique used, or by the fact that, when testing frozen semen samples with a low concentration of target molecules, it is likely that Neospora DNA will be absent in each tube of the reaction, resulting in a false negative PCR result.

The nucleotide sequence obtained from the semen sample where $N$. caninum DNA was detected presented $99 \%$ identity with sequences deposited in GenBank, and, among them, a sequence deposited by Hughes et al. [23], who detected the presence of $N$. caninum in $18.9 \%$ of brain samples from aborted lambs, but not in other tissues, such as heart and umbilical cord samples, from these fetuses.

Our results indicate that further studies are needed to evaluate the real potential of $N$. caninum transmission via semen, like using one protozoa isolated from semen of naturally infected rams to inseminate ewes. There is a variation in degrees of pathogenicity among different protozoan isolates that has already been demonstrated experimentally for the $N$. caninum parasite, such as different viability in vitro [37], transplacental transmission [8,36], and histopathological lesions [34]; however, no study has evaluated the horizontal transmission capacity (via semen) of different isolates. The experimental study of Syed-Hussain et al. [42] demonstrated that the transmission of $N$. caninum via semen in sheep is unlikely, since ewes that had copulated with rams experimentally infected with the NcNZ1 isolate and that had $N$. caninum in semen did not present seroconversion. However, further studies with different isolates are required to confirm the non-transmission of $N$. caninum via semen.

The nucleotide sequence obtained from the T. gondii DNA-positive semen sample showed $100 \%$ identity with many sequences deposited in the Gen- 
Bank database, and, among them, T. gondii sequences obtained from sheep tissue samples, confirming the result obtained by PCR.

It is suggested that a new parasite elimination pathway is occurring among rams used for reproduction, due to the presence of $N$. caninum and T. gondii DNA in fresh semen samples from seropositive animals. Although the detection of genomic DNA of $N$. caninum and $T$. gondii in semen does not necessarily imply the presence of infectious stages of the parasites and does not determine their viability, these results demonstrate the need for further studies.

Our study also indicates the need to reinforce preventive measures for sheep in artificial insemination centers until the risks are evaluated, by performing serological examinations with anti- $N$. caninum and anti- $T$. gondii antibodies, for instance, to select the rams that will be used for breeding.

\section{CONCLUSION}

This study demonstrated that naturally infected rams with Neospora caninum and Toxoplasma gondii can eliminate the protozoa through semen.

\section{MANUFACTURERS}

${ }^{1}$ Sigma-Aldrich Brazil. São Paulo, SP, Brazil.

${ }^{2}$ Invitrogen. Carlsbad, CA, USA.

${ }^{3}$ MGM Assessoria Biológica. Campo Magro, PR, Brazil.

Acknowledgements. This research did not receive any specific grant from funding agencies in the public, commercial, or notfor-profit sectors.

Ethical approval. This Project was approved by the Animal Ethics Committee of the Department of Agricultural Sciences (CEUA SCA) under the protocol number 065/2016.

Declaration of interest. The authors report no conflicts of interest. The authors alone are responsible for the content and writing of the paper.

\section{REFERENCES}

1 Aganga A.O., Umoh J.U., Kyewalabye E.K. \& Ekwempu C.C. 1988. Comparative experimental transmission studies with Nigerian isolates and TS-I strain of Toxoplasma gondii in sheep. Journal of Animal Production Research. 8: 104-120.

2 Arantes T.P., Lopes W.D.Z., Ferreira R.M., Pieroni J.S.P., Pinto V.M.R., Sakamoto C.A. \& Costa A.J. 2009. Toxoplasma gondii: Evidence for the transmission by semen in dogs. Experimental Parasitology. 123(2): 190-194.

3 Baszler T.V., Gay L.J.C., Long M.T. \& Mathison B.A. 1999. Detection by PCR of Neospora caninum in Fetal Tissues from Spontaneous Bovine Abortions. Journal of Clinical Microbiology. 37(12): 4059-4064.

4 Bezerra M., Cruz J., Kung E., Albuquerque P., Kim P., Moraes E.P., Pinheiro Júnior J.W. \& Mota R.A. 2014. Detection of Toxoplasma gondii DNA in Fresh and Frozen Semen from Rams in Brazil. Reproduction in Domestic Animals. 49(5): 753-755.

5 Burg J.L., Grover C.M., Pouletty P. \& Boothroyd J.C. 1989. Direct and sensitive detection of a pathogenic protozoan, Toxoplasma gondii, by polymerase chain reaction. Journal of Clinical Microbiology. 27(8): 1787-1792.

6 Buxton D. 1990. Ovine toxoplasmosis: a review. Journal of the Royal Society of Medicine. 83(8): 509-511.

7 Caetano-Da-Silva A., Ferre I., Collantes-Fernández E., Navarro V., Aduriz G., Ugarte-Garagalza C. \& OrtegaMora L.M. 2004. Occasional detection of Neospora caninum DNA in frozen extended semen from naturally infected bulls. Theriogenology. 62(7): 1329-1336.

8 Chryssafidis A.L., Cantón G., Chianini F., Innes E.A., Madureira E.H. \& Gennari S.M. 2014. Pathogenicity of Nc-Bahia and Nc-1 strains of Neospora caninum in experimentally infected cows and buffaloes in early pregnancy. Parasitology Research. 113(4): 1521-1528.

9 De Moraes É.P.B.X., Batista A.M., Faria E.B., Freire R.L., Freitas A.C., Silva M.A., Braga V.A. \& Mota R.A. 2010. Experimental infection by Toxoplasma gondii using contaminated semen containing different doses of tachyzoites in sheep. Veterinary Parasitology. 170(3-4): 318-322.

10 De Moraes E.P.B.X., da Costa M.M., Dantas A.F.M., da Silva J.C.R. \& Mota R.A. 2011. Toxoplasma gondii diagnosis in ovine aborted fetuses and stillborns in the State of Pernambuco, Brazil. Veterinary Parasitology. 183(1-2): 152-155.

11 Doosti A., Khamesipour F., Nekoei S. \& Lutvikadic I. 2015. Survey for the presence of Neospora caninum in frozen bull's semen samples by PCR assay. Asian Pacific Journal of Tropical Disease. 5(1): 7-12.

12 Dubey J.P. \& Lindsay D.S. 1990. Neospora caninum induced abortion in sheep. Journal of Veterinary Diagnostic Investigation. 2(3): 230-233. 
13 Dubey J.P. \& Schares G. 2011. Neosporosis in animals-The last five years. Veterinary Parasitology. 180(1-2): 90-108.

14 Dubey J.P., Schares G. \& Ortega-Mora L.M. 2007. Epidemiology and control of neosporosis and Neospora caninum. Clinical Microbiology Reviews. 20(2): 323-367.

15 Dubey J.P. \& Sharma S.P. 1980. Prolonged excretion of Toxoplasma gondii in semen of goats. American Journal of Veterinary Research. 41(5): 794-795.

16 Ferra J.D.C. \& Sereno J.R.B. 2006. Artificial Insemination in sheep. Planaltina, DF: Embrapa Cerrados (ISSN 15175111; 156), 26 p. Disponível em: <http://ainfo.cnptia.embrapa.br/digital/bitstream/CPAC-2009/27833/1/doc_156.pdf.> [Accessed online in October 2018].

17 Ferre I., Aduriz G., Del-Pozo I., Regidor-Cerrillo J., Atxaerandio R., Collantes-Fernandez E., Hurtado A., Ugarte-Garalgaza C. \& Ortega-Mora L.M. 2005. Detection of Neospora caninum in the semen and blood of naturally infected bulls. Theriogenology. 63(5): 1504-1518.

18 Ferre I., Serrano-Martínez E., Martínez A., Osoro K., Mateos-Sanz A., del-Pozo I., Aduriz G., Tamargo C. \& Ortega-Mora L.M. 2008. Effects of re-infection with Neospora caninum in bulls on parasite detection in semen and blood and immunological responses. Theriogenology. 69(7): 905-911.

19 Fuentes I., Rodriguez M., Domingo C.J., Del Castillo F., Juncosa T. \& Alvar J. 1996. Urine sample used for congenital toxoplasmosis diagnosis by PCR. Journal of Clinical Microbiology. 34(10): 2368-2371.

20 Giadinis N.D., Terpsidis K., Diakou A., Siarkou V., Loukopoulos P., Osman R., Karatzias H. \& Papazahariadou M. 2011. Massive toxoplasma abortions in a dairy sheep flock and therapeutic approach with different doses of sulfadimidine. Turkish Journal of Veterinary and Animal Sciences. 35(3): 207-211.

21 González-Warleta M., Castro-Hermida J.A., Regidor-Cerrillo J., Benavides J., Álvarez-García G., Fuertes M., Ortega-Mora L.M. \& Mezo M. 2014. Neospora caninum infection as a cause of reproductive failure in a sheep flock. Veterinary Research. 45(1): 88.

22 Guimarães A., Raimundo J.M., Moraes L.M.B., Silva A.T., Santos H.A., Pires M.S., Machado R.Z. \& Baldani C.D. 2015. Occurrences of anti-Toxoplasma gondii and anti-Neospora caninum antibodies in sheep from four districts of Tocantins state, Brazilian Legal Amazon Region. Pesquisa Veterinária Brasileira. 35(2): 110-114.

23 Hughes J.M., Williams R.H., Morley E.K., Cook D.A., Terry R.S., Murphy R.G., Smith J.E. \& Hide G. 2006. The prevalence of Neospora caninum and co-infection with Toxoplasma gondii by PCR analysis in naturally occurring mammal populations. Parasitology. 132(Pt 1): 29-36.

24 Jozani R.J., Asadpour R., Nematolahi A. \& Hosseininejad M. 2012. Detection of non-spermatozoal cells of Neospora caninum in fresh semen of naturally infected bulls. Acta Scientiae Veterinariae. 40(2): 1-7.

25 Koch M.O., Weiss R.R., Cruz A.A., Soccol V.T., Gonçalves K.A., Bertol M.A.F., Beltrame O.C. \& Dittrich R.L. 2016. Detection and isolation of Toxoplasma gondii from fresh semen of naturally infected dogs in Southern Brazil. Reproduction in Domestic Animals. 51(4): 550-554.

26 Locatelli-Dittrich R., Dittrich J.R., Richartz R.R.T.B., Gasino Joineau M.E., Antunes J., Pinckney R.D., Deconto I., Hoffmann D.C. \& Thomaz-Soccol V. 2006. Investigation of Neospora sp. and Toxoplasma gondii antibodies in mares and in precolostral foals from Parana State, Southern Brazil. Veterinary Parasitology. 135(3-4): 215-221.

27 Lopes W.D.Z., da Costa A.J., Santana L.F., dos Santos R.S., Rossanese W.M., Lopes W.C.Z, Costa G.H.N., Sakamoto C.A. \& dos Santos T.R. 2009. Aspects of toxoplasma infection on the reproductive system of experimentally infected rams (Ovis aries). Journal of Parasitology Research. 2009(Article ID 602803): 1-6.

28 Lopes W.D.Z., Rodriguez J.D.A., Souza F.A., dos Santos T.R., dos Santos R.S., Rosanese W.M., Lopes W.R., Sakamoto C.A. \& da Costa A.J. 2013. Sexual transmission of Toxoplasma gondii in sheep. Veterinary Parasitology. 195(1-2): 47-56.

29 Moraes É.P.B.X., Faria E.B., Batista A.M., Freitas A.C., Silva J.C.R., Albuquerque P.P.F. \& Rinaldo A.M. 2010. Toxoplasma gondii detection in the semen of naturally infected sheep. Pesquisa Veterinária Brasileira. 30(11): 915-917.

30 Moraes L.M.B., Raimundo J.M., Guimarães A., Santos H.A., Macedo Junior G.L., Massard C.L., Machado R.Z. \& Baldani C.D. 2011. Occurrence of anti-Neospora caninum and anti-Toxoplasma gondii IgG antibodies in goats and sheep in western Maranhão, Brazil. Revista Brasileira de Parasitologia Veterinária. 20(4): 312-317.

31 Moura A.B., Costa A.J., Jordão Filho S., Paim B.B., Pinto F.R. \& Di Mauro D.C. 2007. Toxoplasma gondii in semen of experimentally infected swine. Pesquisa Veterinária Brasileira. 27(10): 430-434.

32 Olafson P. \& Monlux W.S. 1942. Toxoplasma gondii infection in animals. The Cornell Veterinarian. 32(2): 176-190. 
33 Ortega-Mora L.M., Ferre I., Del-Pozo I., Caetano-Da-Silva A., Collantes-Fernández E., Regidor-Cerrillo J., Ugarte-Garagalza C. \& Aduriz G. 2003. Detection of Neospora caninum in semen of bulls. Veterinary Parasitology. 117(4): 301-308.

34 Pereira García-Melo D., Regidor-Cerrillo J., Collantes-Fernández E., Aguado-Martínez A., Del Pozo I., Minguijón E., Gómez-Bautista M., Aduriz G. \& Ortega-Mora L.M. 2010. Pathogenic characterization in mice of Neospora caninum isolates obtained from asymptomatic calves. Parasitology. 137(7): 1057-1068.

35 Pinto A.P., Bacha F.B., Santos B.S., Driemeier D., Antoniassi N.A.B., de Sá Ribas N.L.K. \& Lemos R.A.A. 2012. Sheep abortion associated with Neospora caninum in Mato Grosso do Sul, Brazil. Pesquisa Veterinaria Brasileira. 32(8): 739-742.

36 Regidor-Cerrillo J., Gomez-Bautista M., Del Pozo I., Jimenez-Ruiz E., Aduriz G. \& Ortega-Mora L.M. 2010. Influence of Neospora caninum intra-specific variability in the outcome of infection in a pregnant BALB/c mouse model. Veterinary Research. 41(4): 41-52.

37 Rojo-Montejo S., Collantes-Fernandez E., Regidor-Cerrillo J., Alvarez-Garcia G., Marugan-Hernandez V., Pedraza-Dias S., Blanco-Murcia J., Prenafeta A. \& Ortega-Mora L.M. 2009. Isolation and characterization of a bovine isolate of Neospora caninum with low virulence. Veterinary Parasitology. 159(1): 7-16.

38 Santana L.F., da Costa A.J., Pieroni J., Lopes W.D.Z., Santos R.S., de Oliveira G.P., de Mendonça R.P. \& Sakamoto C.A.M. 2010. Detection of Toxoplasma gondii in the reproductive system of male goats. Revista Brasileira de Parasitologia Veterinária. 19(3): 179-182.

39 Scarpelli L., Lopes W.D.Z., Migani M., Bresciani K.D.S. \& Da Costa A.J. 2009. Toxoplasma gondii in experimentally infected Bos taurus and Bos indicus semen and tissues. Pesquisa Veterinária Brasileira. 29(1): 59-64.

40 Sharifzadeh A., Doosti A. \& Dehkordi P.G. 2012. PCR assay for detection of Neospora caninum in fresh and frozen semen specimens of Iranian bulls. World Applied Sciences Journal. 17(6): 742-749.

41 Spence J.B., Beattie J., Faulkner L. \& Watson W.A. 1978. Toxoplasma gondii in the semen of rams. Veterinary Record. 102(2): 38-39.

42 Syed-Hussain S.S., Howe L., Pomroy W.E., West D.M., Smith S.L. \& Williamson N.B. 2013. Detection of Neospora caninum DNA in semen of experimental infected rams with no evidence of horizontal transmission in ewes. Veterinary Parasitology. 197(3-4): 534-542.

43 Teale A.J., Blewett D.A. \& Miller J.K. 1982. Experimentally induced toxoplasmosis in young rams: The clinical syndrome and semen secretion of Toxoplasma. Veterinary Record. 111(3): 53-55.

44 Weissmann J. 2003. Presumptive Toxoplasma gondii abortion in a sheep. Canadian Veterinary Journal. 44(4): $322-$ 324.

45 Weston J.F., Howe L., Collett M.G., Pattison R.S., Williamson N.B., West D.M., Pomroy W.E., Syed-Hussain S.S., Morris S.T. \& Kenyon P.R. 2009. Dose-titration challenge of young pregnant sheep with Neospora caninum tachyzoites. Veterinary Parasitology. 164(2-4): 183-191.

46 Yamage M., Flechtner O. \& Gottstein B. 1996. Neospora caninum: Specific oligonucleotide primers for the detection of brain "cyst" DNA of eperimentally infected nude mice by the polymerase chain reaction (PCR). The Journal of Parasitology. 82(2): 272-279. 